\title{
Información y Novedades
}

\section{EVENTOS}

- II Congreso Argentino de Anatomía Clínica: Tucumán, Argentina, 8 al 10 de setiembre de 2011. www.aaanatomiaclinica.com.ar

- XXV Congreso de la Sociedad Anatómica Española. Madrid, España, 14 al 17 de setiembre de 2011. www.xxvcongresosae.com

- $\quad 1^{\circ}$ Congreso de Patología de Macedonia. Ohrid, República de Macedonia, 12 al 16 de octubre de 2011. www.pathology2011.com

- $18^{\circ}$ Congreso de la Federación Internacional de Asociaciones de Anatomistas (IFAA): Beijing, China, 8 al 10 de agosto de 2014. www.bicc.com.cn y www.bcghotel.com.

\section{CONVOCATORIA}

\section{PORTADA DE LA REVISTA}

Invitamos a todos suscriptos a la Revista Argentina de Anatomía Clínica y a los miembros de la Asociación Argentina de Anatomía Clínica a enviar imágenes (fotografías, dibujos, caricaturas, etc.) para ser incluidas en la portada de la Revista.

Las imágenes deberán ser originales, relacionadas a la Anatomía Clínica, a la Educación Médica en Anatomía, a los contenidos o actividades de la Revista Argentina de Anatomía Clínica o a las actividades de Asociación Argentina de Anatomía Clínica; poseer buena calidad a los fines de su edición, adaptarse al espacio disponible, no haber sido publicadas de modo formal o informal (internet) con antelación, contar con título y nombre del autor.

Se enviarán a través del sitio web de la Revista. Serán seleccionadas por el/la Editor en Jefe y el Consejo Editorial. En caso de considerarse conveniente, se podrá dar participación a los suscriptores. Sus imágenes encabezarán los próximos números.

Prof. Dra. Susana N. Biasutto

Editor en Jefe

Revista Argentina de Anatomía Clínica

\section{PUBLICACIONES}

\section{Atlas fotográfico en color del sistema nervioso central}

V. Di Marino, Y. Etienne, M. Niddam

Este Atlas incluye 350 fotografias color de excepcional calidad with creciente definición neuroanatómica de las estructuras del sistema nervioso central por adición de transparencias, de cloridoférrico (proceso de coloración descubierto por los autores).

Todo en todo, un libro interesante no solo para estudiantes de medicina sino también para neruoradiólogos, neuro-científicos y neurólogos. 


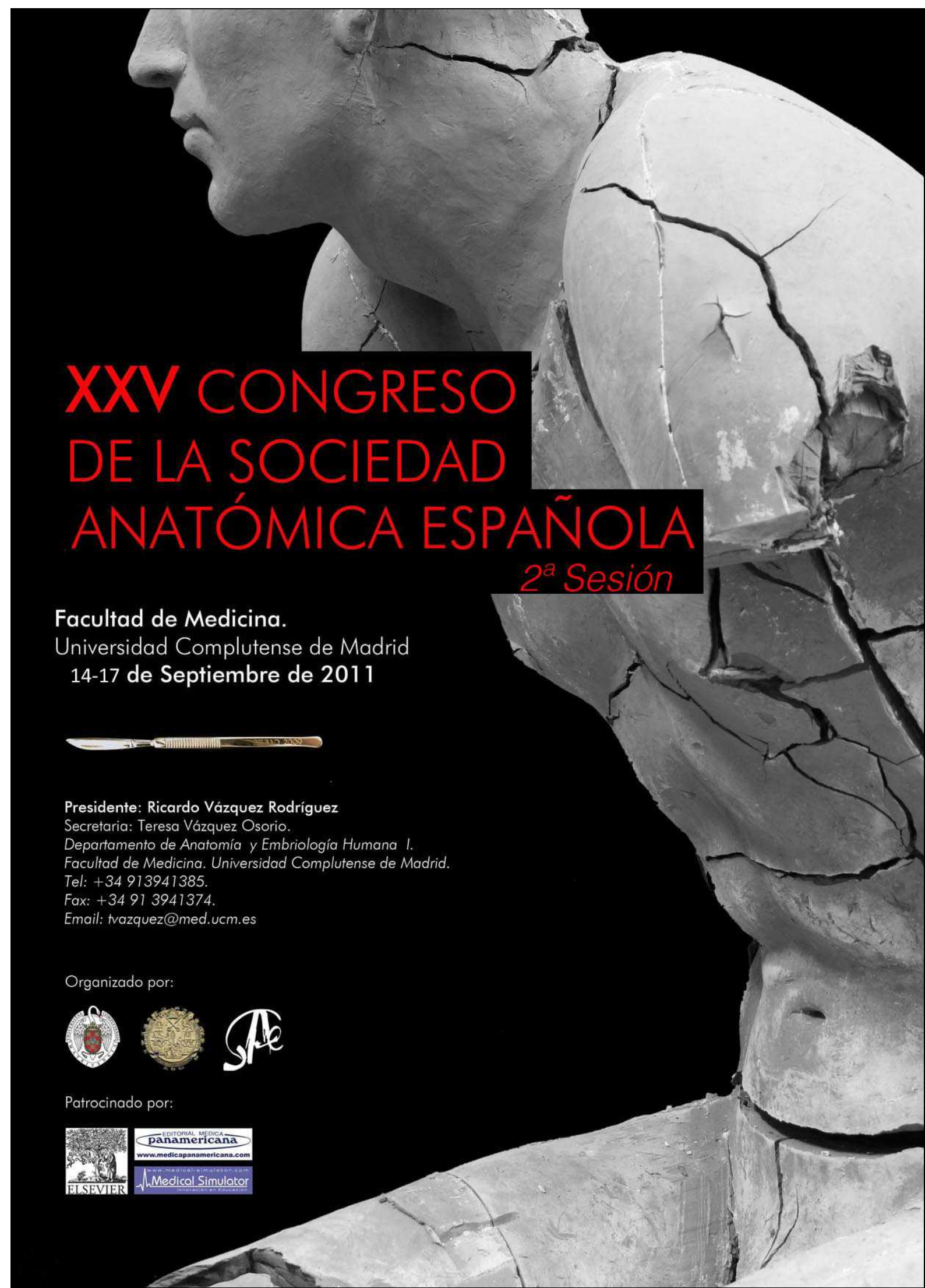

